year I897," p. 7):-It may be interesting to mention that shortly before noon on August I last year a large meteorite fell at Zavid near Rožanj, in the district of Zvornik. Unfortunately, as soon as it cooled, peasants of the neighbourhood knocked off pieces of it, but about 80 per cent. of the mass remained. It buried itself a yard deep in the ground, with the so-called breast uppermost. Eye-witnesses of its fall say that it was accompanied by a noise like thunder, lasting several minutes and audible a long way off. It left a fiery streak behind, which a short way above the horizon divided in two, and above this streak or tail was a thick cloud of smoke. This meteorite is now in the museum of this town, and measures 55 by 35 by 28 centims. It was broken by the fall in several pieces, but has been joined together again. This is the first aerolite which bas been found in Bosnia.

The New Observatory at Heidelberg. - The opening of the new observatory at Heidelberg, on June 20 , is an event of no little importance, more especially as the instrumental equipment is designed for the pursuit of both of the great branches of astronomy. The astrometric department is in the capable hands of Prof. Valentin, who, in addition to more purely scientific problems, is charged with the determination of time and its communication to the railways and various other establishments. The most important instrument is a meridian circle by Repsold, of 6 inches aperture.

Prof. Max Wolf, who has achieved such brilliant success in celestial photography, is in charge of the astrophysical work of the observatory, and we are glad to know that the buildings have been specially arranged to facilitate the continuation of his researches. The equatorial, which has served Prof. Wolf so well, is placed under a dome of nearly i8 feet diameter, the construction of which is so perfect that it can be turned completely round in 8 seconds. Another dome of nearly 20 feet diameter will shelter the astrophotograpkic instrument, which the observatory will owe to the generosity of Miss Bruce. The lenses for this instrument are being made by Brashear.

An Astronomer's Reminiscences. - In the first of a series of "Reminiscences of an Astronomer," which Prof. Simon Newcomb contributes to the August number of the Atlantic Monthly, several incidents and opinions of interest to astronomers are related. Referring to Cayley, Prof. Newcomb says : "His life was that of a man moved to investigation by an uncontrollable impulse ; the only sort of man whose work is destined to be imperishable." After a short description of the work of Leverrier and Adams, which led to the discovery of Neptune, we read: "Adams's intellect was one of the keenest I ever knew. The most difficult problems of mathematical astronomy and the most recondite principles that underlie the theory of the celestial motions were to him but child's play." Airy is regarded as "the most commanding figure in the astronomy of our time. He owes this position not only to his early works in mathematical astronomy, but also to his ability as an organiser." Experience in the United States led Prof. Newcomb to anticipate a difficulty in getting the various telegraph stations between Gibraltar and Greenwich connected for longitude operations, and in discussing the work he asked Airy how the connections could be made from one end of the line to the other, at the same moment. " Nothing is simpler," replied Airy. "I set a moment, say eight o'clock Greenwich mean time, at which signals are to commence. Every intermediate office through which the signals are to pass is instructed to have its wires connected in both directions exactly at the given hour, and to leave them so connected for ten minutes, without asking any further instructions. At the end of the line the instrument must be prepared at the appointed hour to receive the signals. All I have to do here is to place my clock in the circuit and send on the signals for ten minutes commencing at eight o'clock. They are recorded at the other end of the line, without further trouble." This incident is a good lesson in astronomical method.

\section{THE FORTHCOMING INTERNATIONAL CONGRESS OF ZOOLOGY}

THE following is the programme of the fourth International Congress of Zoology, which begins at Cambridge on Monday next, under the patronage of H.R.H. the Prince of Wales, and the presidency of the Right Hon. Sir John Lubbock, Bart., M.P., F.R.S. :-

NO. I 503 , VOL. 58 ]
The Reception Room (Masonic Hall, Corn Exchange Street) will be open from 9 a.m. to 7 p.m. on Monday, August 22, and on the four following days; and from 9 a.m. to I p.m. on Saturday, August 27.

Monday, August 22, 9 p.m. to II p.m.-Reception at the Guildhall by the Mayor of Cambridge. Members of the University and of the Town Council are requested to wear gowns; Doctors and Aldermen, scarlet.

\section{Proceedings of the Congress.}

Tuesday, August 23, 10.30 a.m., at the Guildhall.-Opening of the Congress by the President. Election of officers. Keceipt of reports of Committees appointed by the third Congress, and other business. 2 p.m. : Meetings of the Sections.

Note. - The Sections will be : $(a)$ General Zoology, at the Guildhall (No. I on the plan of the museums on the members tickets); (b) Vertebrata, in the Lecture Room of the Cavendish Laboratory (No. 2 on the plan); (c) Invertebrata (except the Arthropoda), in the Lecture Room of the Chemical Laboratory (No. 4 on the plan); $(d)$ Arthropoda, in the Lecture Room of Comparative Anatomy (No. 6 on the plan). 5.50 p.m.: Organ recital in King's College Chapel. 9 p.m. to I I p.m. : Reception by the Vice-Chancellor at Downing College.

Wednesday, August 24, I0.30 a.m., at the Guildhall.General meeting of the Congress to discuss the position of sponges in the animal kingdom. The discussion will be opened by Prof. Yves Delage, of Paris, and Mr. Minchin, of Oxford.

Note. - There may also be meetings of the Sections. 2 p.m. : Meetings of the Sections. 9 p.m.: Conversazione in the Fitzwilliam Museum in conjunction with the International Congress of Physiologists.

Thursday August 25, 10.30 a.m., at the Guildhall. - General meeting of the Congress to discuss the origin of Mammals. The discussion will be opened by Prof. Seeley, of London, and Prof. H. F. Osborn, of New York.

Note. - There may also be meetings of the Sections. 2. I 5 p.m., at the Senate House: The conferring of honorary degrees. 4-6.30 p.m. : Garden party in the Botanic Garden of the University.

Friday, August 26, 13.30 a.m., at the Guildhall.-General meeting of the Congress to hear an address by Prof. Haeckel, "On our present knowledge of the Descent of Man." The Right Hon. Sir Herbert Maxwell, Bart., M.P., will afterwards read a paper "On recent Legislation on the Protection of Wild" Birds in Britain."

Note.--There may also be meetings of the Sections. 2 p.m. Meetings of the Sections. 7.30 p.m.: Dinner in the hall of Trinity College. Tickets, price I5s., must be applied for in the Reception Room not later than I p.m. on Wednesday, August 24

Saturday, August 27, 9.30 a.m., at the Guildhall.-General meeting of the Congress to settle the time and place of the Filth International Congress.

\section{Arrangements for the Congress in Landon.}

Saturday, August 27, 4 p.m. to 7 p.m.-Reception by the President and Council of the Zoological Society of London in their gardens in the Regent's Park, London. Tea and light refreshments will be served. 9 to II.30 p.m. : Reception by the Right Hon. Sir John Lubbock, President of the Congress, of the members of the Congress, at the Natural History Museum, Cromwell Road.

Sunday, August 28, 2.30 p.m. to 7 p.m. : The Natural History Museum, Cromwell Road, will be open. Tea and light refreshments will be served to members of the Congress from 4 p.m. to 6 p.m. 9 p.m. : The President and Committee of the Royal Societies' Club, St. James's Street, S.W., will hold a reception in honour of the Congress (gentlemen only).

Monday, August 29.-Visit to Tring Museum. Visitors will be received by the Hon. Walter Rothschild, who will entertain them at lunch.

Note.-Notice of intention to visit Tring must be given in writing to the Secretaries not later than noon on Wednesday, August 24.

Tuesday, August 30.-His Grace the Duke of Bedford will be glad if such zoologists as are interested in the study of the Cervidæ will visit his parks at Woburn on Tuesday, August 30. Mr. R. Lydekker, F.R.S., has promised to conduct the party, which should not exceed in number sixty. Further information 
may be obtained by applying to Mr. Lydekker, at The Lodge, Harpenden, Herts.

Monday and Tuesday, August 29 and 30.-The museum of the Royal College of Surgeons will be open to members of the Congress on production of their ticket. An official of the museum will be present to receive visitors.

Tuesday, Wednesday and Thursday, August 30 and $3 \mathrm{I}$, and September 1.-Dredging expeditions at Plymouth with the Director of the Marine Biological Laboratory, and at Port Erin, Isle of Man, under the direction of Prof. Herdman, F.R.S.

Note.-Visitors to either of these dredging expeditions should give notice to the Secretaries in writing as early as possible.

The gardens of the Zoological Society of London will be open to members of the Congress on showing their tickets and writing their names in the book at the gates every day, including Sunday, from Thursday, August 18, to Thursday, September I, inclusive.

The Committee of the Royal Societies' Club, St. James's Street, S.W., will extend the privileges of honorary membership to members of the Congress (not ladies) on presentation of their cards of Congress membership, from August 18 to September $\mathrm{I}$, inclusive. Members of the Congress making use of the Club must enter their names in the visitors' book.

The President and Council of the Linnean Society, Burlington House, Piccadilly, will throw open their apartments to the members of the Congress of Zoology from August 27 to September $I$, inclusive.

The gardens of the Royal Zoological Society of Ireland will be open to members of the Congress who visit Dublin on presenting their cards of membership at the gate.

\section{A YORKSHIRE MOOR. ${ }^{1}$}

I.

THE Yorkshire moor is high, ill-drained, peaty, and overgrown with heather. Moors of this type abound in Scotland, and creep southward along the hills into Yorkshire and Derbyshire, breaking up into smaller patches as the elevation declines. In the south of England they become rarer, though famous examples occur in Dartmoor and Exmoor. In the north they may cover great stretches of country. It used to be said that a man might walk from Ilkley to Glasgow without ever leaving the heather. That was never quite true, but even to.day it is not far from the truth; a man might walk nearly all the way on unenclosed ground, mostly moorland.

Neither peat nor heather is confined to high ground. Peat often forms at sea-level, and may contain the remains of sea-weed. In some places it is actually submerged by change of sea-level, and the peasants go at low water and dig through the sand to get it. Heather ranges from sea-level to Alpine heights.

Peat may form because there is no fall to carry off the water, or because the soil, though high and sloping, is impermeable to water. A few feet of stiff boulder-clay. constitute such an impermeable floor, and a great part of our Yorkshire moors rests upon boulder-clay, which is attribufed to ice-action, because it is often packed with ice-scratched pebbles, some of which have travelled far, and because the rock beneath, when bared, exhibits similar scratches.

The rocks beneath the boulder-clay of a Yorkshire moor are chiefly sandstones and shales. Where the sandstones crop out, they form tolerably bold escarpments with many fallen blocks, such as we call "edges" in the north; the shales make gentler slopes. Both the surface-water and the spring-water of the moors are pure and soft; they may be tinged with peat, but they contain hardly any lime, potash, or other mineral substance except iron-oxides.

The wettest parts of the moor are called mosses (in some parts of Scotland they are called flow-mosses) because the Sphagnum-moss grows there in profusion. The Sphagnumswamps are an important feature of the moor, if only because they form a great part of the peat. Not all the peat, however; some is entirely composed of heather and heath-like plants, while now and then the hair-moss (Polytrichum) and certain moorland lichens contribute their share, but the Sphagnum. swamps play the leading part, especially in starting new growths 1 A discourse given at the Royal Institution, February 1898 . By L. C. Miall, F.R.S.

NO. I 503 , VOL. 587 of peat. If we walk carelessly over the moor, we now and then step upon a bed of Sphagnum. We have hardly time to notice its pale green tint and the rosy colour of the new growths before all close observation is arrested by the cold trickle of water into the boots. The practised rambler takes care to keep out of the Sphagnum swamps altogether, knowing that he may easily sink to the knees or further. Sphagnum sucks up water like a sponge, and if you gather a handful, you will be surprised to see how much water can be squeezed out of it. This water abounds in microscopic life; Amœbre and other Rhizopods, Diatoms, Infusoria, Nematoids, Rotifers and the like can be obtained in abundance by squeezing a little Sphagnum fresh from the moors. ${ }^{1}$ As the stems of Sphagnum grow upwards, they die at the base, and form a brown mass, which at length turns black, and in which the microscope reveals characteristic structural details, years, perhaps centuries after the tissues ceased to live.

An old Sphagnum moss is sometimes a vast spongy accumulation of peat and water, rising higher in the centre than on the sides, and covered over by a thin living crust. The interior
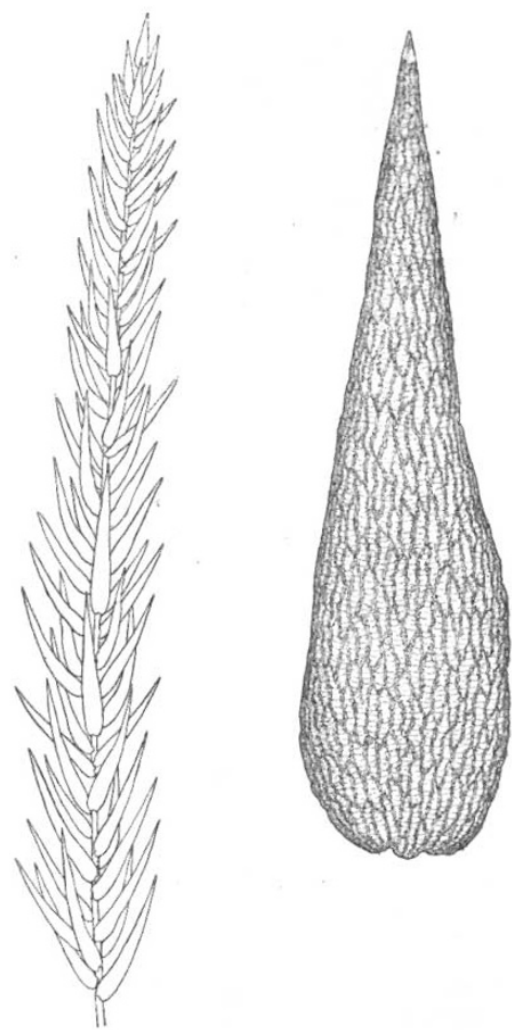

FIG. I.-Leafy branch of Sphagnum, magnified; one leaf of ditto, further magnified.

may be half-liquid, and when the crust bursts after heavy rain, the contents of a hillside-swamp now and then pours forth in an inky flood, deluging whole parishes. In 1697 a bog of 40 acres burst at Charleville, near Limerick. In 1745 a bog burst in Lancashire, and speedily covered a space a mile long and half a mile broad. A bog at Crowhill on the moors near Keighley burst in I 824, and coloured the river with a peaty stain as far as to the Humber. In December 1896 , a bog of 200 acres burst at Rathmore near Killarney, and the effects were seen ten miles off. Nine persons perished in one cottage.

The soaking-up of water is essential to the growth of the Sphagnum, which employs several different expedients for this purpose. Its slender stems give off numerous leafy branches, and also branches which are reduced to filaments. These last turn downwards along the stem, which they may almost conceal

$1 \mathrm{It}$ is interesting to note that the same abundance of animal life characterises the mosses of Spitzbergen, where not a few of the very same species are found. (D. J. Scourfield," Non-marine Fauna of Spitzbergen," Proc. Zool. Soc., 1897.) 